\title{
Tissue ingrowth within lumen-apposing metal stents. How long is long term?
}

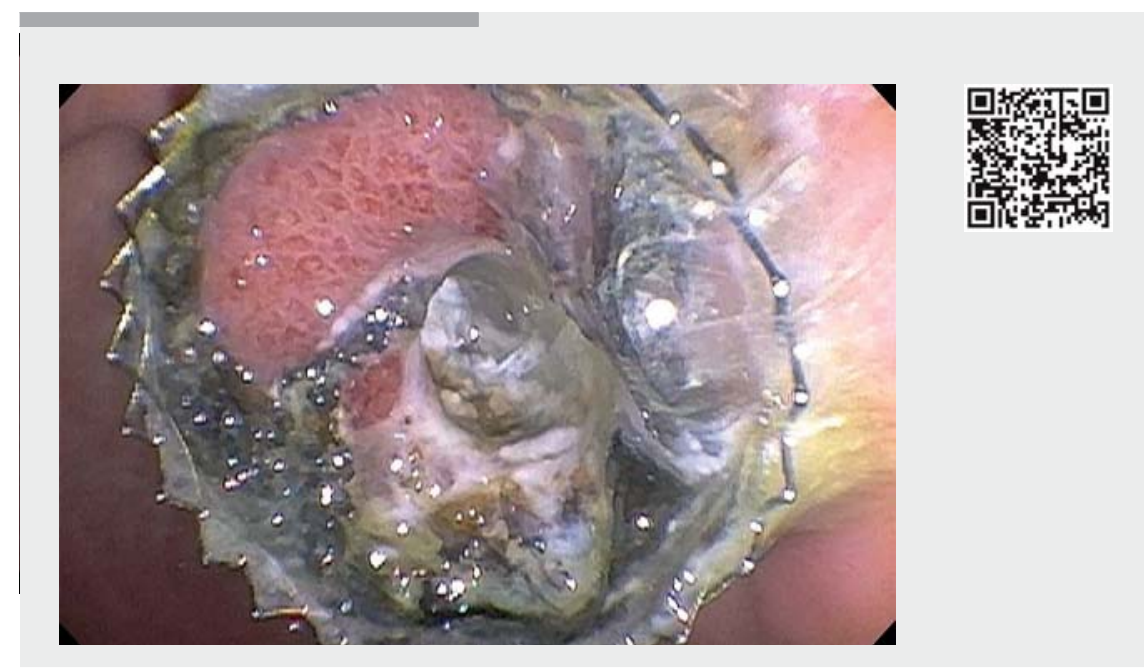

Video 1 Lumen-apposing metal cyst-gastrostomy stent with visible tissue ingrowth and erosion of the plastic covering.

A 31-year-old woman with a history of alcohol pancreatitis presented with abdominal pain. During her initial admission, she developed an $8.2-\mathrm{cm}$ peripancreatic fluid collection. She underwent successful endoscopic ultrasoundguided drainage of the collection with a $15 \mathrm{~mm}$ lumen-apposing metal stent (LAMS). Though instructed to return, the patient was lost to follow-up. She returned to an outside hospital 7 months later with recurrent pancreatitis secondary to alcohol use. Imaging demonstrated resolution of the peripancreatic collection, with the cyst-gastrostomy stent still in situ. The initial attempt at stent removal was unsuccessful. She was then transferred to our institution.

During endoscopy the LAMS was seen in the gastric body. Endoscopically, it was evident that the plastic covering had been eroded ( $>$ Video 1 ). There was visible tissue ingrowth into the LAMS. The gastric flange was detached from the gastric mucosa using a snare. However, the distal flange was imbedded in the tissue. After multiple attempts, the distal flange was successfully removed using rat tooth forceps after detaching it from tissue. The fistula site had mild oozing after stent removal. Examination of the removed stent demonstrated obvious tissue ingrowth through the degraded plastic covering ( $>$ Fig. $\mathbf{1}$ ).

After the development of LAMS, endoscopists have created multiple novel anastomoses between various gastrointestinal lumens. Official recommendation from the manufacturing company is to remove these stents 60 days after deployment. However, various studies have demonstrated outcomes beyond 60 days. Examples include pancreatic fluid collections, benign intestinal tract strictures, gallbladder drainage, choledochoduodenostomy [1-4]. LAMS have remained in place for longer than 2 months, and reportedly have remained patent for greater than 6 months. However, degrading of the plastic coating and tissue ingrowth is a known complication of long-term use of LAMS. Therefore, periodic evaluation of these patients is necessary to ensure timely removal.

Endoscopy_UCTN_Code_TTT_1AS_2AD

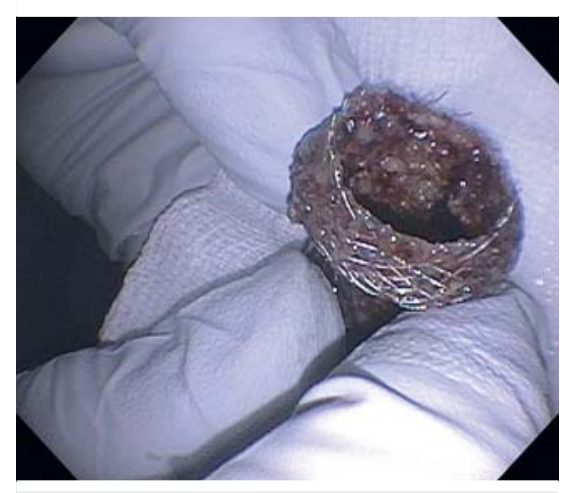

- Fig. 1 The lumen-apposing metal stent after endoscopic removal, with evidence of significant tissue ingrowth through the stent.

\section{Competing interests}

Dr. Sharaiha is a consultant for Boston Scientific Corp. and Apollo Endosurgery. Dr. Locke is a Consultant for Boston Scientific Corp. and has received royalty payments from Steris Corp. and Telemed Systems.

The authors

Monica Saumoy, Luai Madanat, David L. Carr-Locke, Reem Z. Sharaiha

Weill Cornell Medicine, New York Presbyterian Hospital, New York, United States

Corresponding author

Reem Z. Sharaiha, MD

Weill Cornell Medicine, New York

Presbyterian Hospital, 1305 York Ave, 4th Floor, New York, NY 10021, United States Fax: +1-646-962-0110 rzs9001@med.cornell.edu 


\section{References}

[1] Sharaiha RZ, Tyberg A, Khashab MA et al. Endoscopic therapy with lumen-apposing metal stents is safe and effective for patients with pancreatic walled off necrosis. Clin Gastrenterol Hepatol 2016; 14: 1797-1803

[2] Santos-Fernandez ], Paiji C, Shakhatreh M et al. Lumen apposing metal stents for benign gastrointestinal tract strictures: an international multicenter experience. World J Gastrointest Endosc 2017; 9: 571-578

[3] Walter D, Teoh AT, Itoi T et al. EUS-guided gallbladder drainage with a lumen apposing metal stent: a prospective long-term evaluation. Gut 2016; 65: 6-8
[4] Tsuchiya T, Bun Teoh AY, Itoi T et al. Longterm outcomes of EUS-guided choledochoduodenostomy using a lumen-apposing metal stent for malignant distal biliary obstruction: a prospective multicenter study. Gastrointest Endosc 2018; 87: 1138-1146

\section{Bibliography}

DOI https://doi.org/10.1055/a-0631-7854

Published online: 8.8.2018

Endoscopy 2018; 50: E284-E285

(c) Georg Thieme Verlag KG

Stuttgart · New York

ISSN 0013-726X

\section{ENDOSCOPY E-VIDEOS}

https://eref.thieme.de/e-videos

口回 Endoscopy E-Videos is a free 然故 access online section, reporting 回舴: on interesting cases and new techniques in gastroenterological endoscopy. All papers include a high quality video and all contributions are freely accessible online.

This section has its own submission website at

https://mc.manuscriptcentral.com/e-videos 